\title{
Study of a Fuel Supply Pump with a Piezoelectric Effect for Microdirect Alcohol Fuel Cells
}

\author{
Hsiao-Kang Ma, Jyun-Sheng Wang, Wei-Yang Cheng, and Shin-Han Huang \\ Department of Mechanical Engineering, National Taiwan University, Taipei 106, Taiwan \\ Correspondence should be addressed to Hsiao-Kang Ma, skma@ntu.edu.tw
}

Received 16 April 2011; Accepted 12 May 2011

Academic Editor: Shuangyin Wang

Copyright ( $) 2011$ Hsiao-Kang Ma et al. This is an open access article distributed under the Creative Commons Attribution License, which permits unrestricted use, distribution, and reproduction in any medium, provided the original work is properly cited.

\begin{abstract}
A novel design for an ethanol injection system has been proposed, which consists of one pump chamber, two valves, and one central-vibrating piezoelectric device. The system uses a microdiaphragm pump with a piezoelectric device for microdirect alcohol fuel cells. The diameters of the pump chamber are $31 \mathrm{~mm}$ and $23 \mathrm{~mm}$, and the depths of the chamber are $1 \mathrm{~mm}$ and $2 \mathrm{~mm}$. When the piezoelectric device actuates for changing pump chamber volume, the valves will be opened/closed, and the ethanol will be delivered into DAFC system due to the pressure variation. The chamber dimensions, vibrating frequencies of the piezoelectric device, and valve thickness are used as important parameters for the performance of the novel ethanol injection system. The experimental results show that the ethanol flow rate can reach $170 \mathrm{~mL} / \mathrm{min}$ at a vibrating frequency of $75 \mathrm{~Hz}$. In addition, the ethanol flow rate is higher than the water flow rate.
\end{abstract}

\section{Introduction}

During the past 10 years, there has been an increasing interest in the development of direct alcohol/air proton exchange membrane fuel cells (PEMFCs), particularly for applications of the electric vehicle. Low-temperature PEMFCss fueled directly by liquid fuels are gaining more and more attention for their large potential application for fuel cell vehicles, stationary applications, and portable power sources. Operation on liquid fuels without the external bulky fuel-reforming system could greatly simplify the fuel cell system, therefore would result in its rapid commercialization.

DAFCs generate electricity through the direct oxidation of a liquid alcohol fuel in conjunction with the reduction of oxygen (in air). Most DAFCs use a proton-exchange membrane (PEM) as the electrolyte, which makes them a subset of PEMFCs technology. The fuels used in DAFCs include methanol, ethanol, ethylene glycol, and n-propane, among which methanol has the highest electrochemical kinetics. Direct methanol fuel cells (DMFCs) have been extensively investigated, and a significant progress has been made in the development of this type of fuel cell. As compared with methanol, ethanol is more environmental friendly and can be easily mass-produced in large quantities using sugar-containing raw materials from agriculture or biomass. Hence, DAFCs have recently received increased attention.

DAFCs possess a wide spectrum of advantages as compared with PEMFCss that use hydrogen as fuel. As shown in Table 1 [1], the theoretical energy conversion efficiency of all DAFCs exceeds $90 \%$, which is higher than that of PEMFCss (83\%). More importantly, Table 1 shows that liquid alcohols have a much higher volumetric energy density than the hydrogen does. Hence, DAFCs require much smaller fuel cartridges, thus, can be more compact. In addition, DAFCs are easily handled, transported, and stored. Unlike hydrogenfed PEMFCss, DAFCs do not need humidification and separate thermal management ancillary systems. All these features make DAFCs particularly suitable for portable and mobile applications.

Micropumps have many different applications, such as heat dissipation of electronic devices, liquid delivery systems, and fuel injection. In addition, there are many methods for actuating the micropump, such as electromagnetic, piezoelectric, shape memory alloy, electrostatic, and thermopneumatic devices [2-12]. Olsson et al. [13-15] utilized computational fluid dynamics (CFD) to analyze the flow 
TABLE 1: The characteristics of different fuel cell.

\begin{tabular}{lcccccc}
\hline Fuel cell & Fuel/oxidant & $\mathrm{Mw}(\mathrm{g} / \mathrm{mol})$ & $\mathrm{n}$ & $E^{\circ}(\mathrm{V})$ & $E_{\text {sp }}\left(\mathrm{Wh} \mathrm{mL}^{-1}\right)$ & $\eta(\%)$ \\
\hline PEMFCs & $\mathrm{H}_{2}(\mathrm{~g}) / \mathrm{O}_{2}$ & 2.01 & 2 & 1.23 & 85 & 6.973 \\
DMFC & $\mathrm{CH}_{3} \mathrm{OH}(\mathrm{l}) / \mathrm{O}_{2}$ & 32.04 & 6 & 1.21 & 87 \\
DEFC & $\mathrm{C}_{2} \mathrm{H}_{5} \mathrm{OH}(\mathrm{l}) / \mathrm{O}_{2}$ & 46.07 & 12 & 1.15 & 928 & 9.268 \\
DEGFC & $\mathrm{C}_{2} \mathrm{H}_{6} \mathrm{O}_{2}(\mathrm{l}) / \mathrm{O}_{2}$ & 62.07 & 10 & 1.22 & 9.070 \\
DP1FC & $\mathrm{CH}_{3} \mathrm{CH}_{2} \mathrm{CH}_{3} \mathrm{OH}(\mathrm{l}) / \mathrm{O}_{2}$ & 60.10 & 18 & 1.13 & 99 \\
DP2FC & $\mathrm{CH}_{3} \mathrm{CH}(\mathrm{OH}) \mathrm{CH}_{3}(\mathrm{l}) / \mathrm{O}_{2}$ & 60.10 & 18 & 1.12 & 97 \\
\hline
\end{tabular}

fields of different diffusers and nozzles and proposed the lumped-mass model to describe the relationship between the diaphragm and pressure variation. Yang et al. [16] constructed a micropump with a novel bimorph actuation structure that can feed air into DMFCs. Their results showed that the air diaphragm pump worked at a flow rate of $85.3 \mathrm{~mL} / \mathrm{min}$ at low power consumption (below 20 volts). Ma et al. $[17,18]$ presented a one-side actuating microdiaphragm pump with a piezoelectric (PZT) device; it was successfully developed by making use of harmonic resonance of the working liquids with other system components (valve and diaphragm) in the pump chamber. This one-side micropump has also been improved to $250 \mathrm{~mL}$ of water per minute and has the advantages of its high flow rate, simple structure, low power demand, and small size. Zhang and Wang [19] proposed a valveless micro pump for fuel delivery in DMFC devices and suggested that the large driving frequency may decrease the power consumption of the micropump.

Previous studies showed that the air-breathing piezoelectric proton exchange membrane fuel cell (PZT-PEMFCs) can feed air into the cathode channel through a gas pump with a piezoelectric actuation structure [20-24]. This design could solve the water flooding problem and increase cell efficiency. Also, a transitional three-dimensional model is employed to calculate the rib effect on the performance of PEMFCs at different PZT vibrating frequencies. In this study, a novel fuel injection system was designed using a microdiaphragm pump with a piezoelectric device to pump ethanol to a fuel cell. Both ethanol and water were chosen as the working fluids in the experimental study of the fuel injection system performance. The optimal operating parameters include chamber diameter, chamber depth, valve thickness, and PZT vibrating frequency.

\section{Mechanisms of Fuel Injection System}

A novel fuel injection system using a microdiaphragm pump with a piezoelectric device which shown in Figure 1 was designed for pumping fuel to a DAFC. The fuel injection pump consists of one pump chamber, two valves, and one central-vibrating piezoelectric device. Figure 2 indicates an exploded view of the fuel injection pump, which shows the chamber diameter, chamber depth, and valve thickness. When the actuator is moving outward, the volume of the chamber increases, and the ethanol is sucked into the chamber. On the other hand, when the actuator is moving inward, the volume of the chamber is decreased, and the ethanol is delivered to the DAFC.

The driving force of working fluid is actuated by the PZT device. Therefore, the inlet velocity in the chamber is driven by PZT vibrations. The equation of PZT motion is assumed to be the sine function shown in (1):

$$
\vec{V}_{\mathrm{PZT}}=\frac{d}{d t}\{\mathrm{amp} . \times \sin (2 \pi f t)\} .
$$

Also, the inflow and outflow periods in the channel induced by the sine function are shown in Figure 2. The inlet liquid flow rate can be expressed by the Reynolds Transport Theorem as

$$
\begin{aligned}
\frac{D M}{D t}= & \frac{D(\rho \forall)}{D t} \\
= & \frac{\partial}{\partial t} \int_{C \forall} \rho d \forall+\int_{\mathrm{CS}, \mathrm{PZT}} \rho \vec{V}_{\mathrm{PZT}} \cdot \vec{n} d A \\
& +\int_{\mathrm{CS}, \text { in }} \rho \vec{V}_{\mathrm{in}} \cdot \vec{n} d A=0 .
\end{aligned}
$$

Therefore, the inlet velocity can be determined by (2). According the oscillation function of pump's piezoelectric device

$$
F_{\text {input }}-F_{d}=m \frac{d^{2} z_{\mathrm{pzt}}}{d t^{2}}+k z_{\mathrm{pzt}},
$$

$z_{\mathrm{pzt}}$ is the displacement of piezoelectric device, and $m$ is the oscillating fluid mass. $k$ is coefficient of elasticity. When the input strength of piezoelectric device is fixed, the vibrating mass will decrease and the acceleration of the piezoelectric device oscillation will increase. In addition, the chamber volume will decrease, which implies that the required driving fluid quantity for piezoelectric device deformation will decrease, and can provide bigger deformation. When $z_{\mathrm{pzt}}$ is increased, it will lift the net productive flow from pump, in addition, decreasing the pump volume can increase the performance of flow.

In the valve analysis, the passive check valve, which is made of PDMS, is an important device in the design of fuel injection system. The passive check valve decides the performance of the fuel injection system. PDMS is an elastic structural element that can be expressed as a spring motion to store and release energy. When the valve operates in the fluid, the valve's motion will be influenced by the drag force. The performance of fuel injection system can be improved 


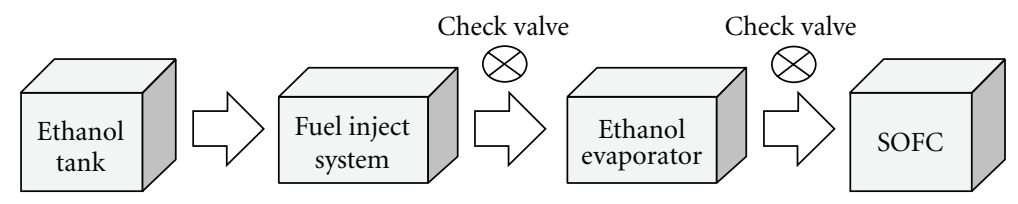

FIgUre 1: The diagram of the fuel injection system.

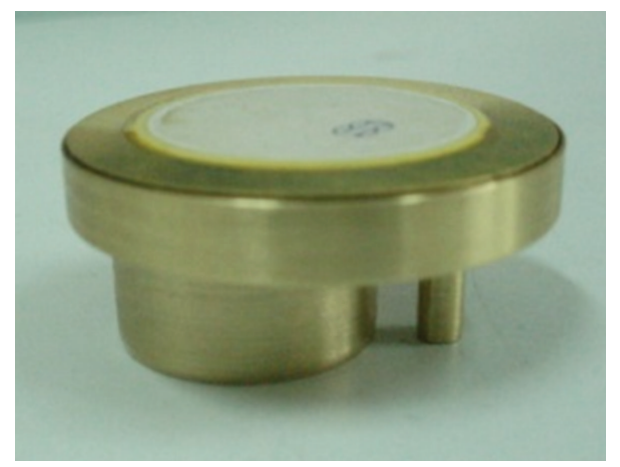

(a)

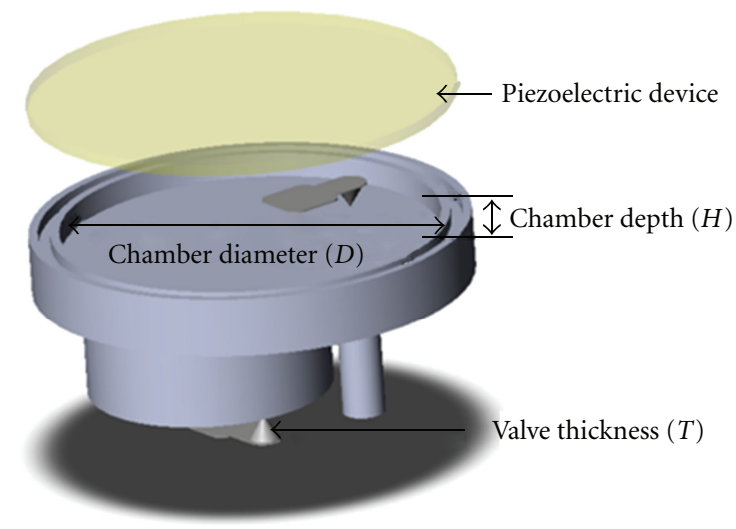

(b)

Figure 2: Assembled fuel injection system and exploded view.

TABLE 2: The design parameters of pump chamber.

\begin{tabular}{lccc}
\hline & $\begin{array}{c}\text { Dimensionless } \\
\text { depth }(H / D)\end{array}$ & $\begin{array}{c}\text { Chamber } \\
\text { depth }(\mathrm{H})\end{array}$ & Valve thickness \\
\hline Case A-1 & $1 / 31$ & $1 \mathrm{~mm}$ & $0.2 \mathrm{~mm}$ \\
Case A-2 & $1 / 31$ & $1 \mathrm{~mm}$ & $0.5 \mathrm{~mm}$ \\
Case B-1 & $2 / 31$ & $2 \mathrm{~mm}$ & $0.2 \mathrm{~mm}$ \\
Case B-2 & $2 / 31$ & $2 \mathrm{~mm}$ & $0.5 \mathrm{~mm}$ \\
Case C-1 & $1 / 23$ & $1 \mathrm{~mm}$ & $0.2 \mathrm{~mm}$ \\
Case C-2 & $1 / 23$ & $1 \mathrm{~mm}$ & $0.5 \mathrm{~mm}$ \\
Case D-1 & $2 / 23$ & $2 \mathrm{~mm}$ & $0.2 \mathrm{~mm}$ \\
Case D-2 & $2 / 23$ & $2 \mathrm{~mm}$ & $0.5 \mathrm{~mm}$ \\
\hline
\end{tabular}

when the motions of the actuator and valves match well; thus, the valve's response plays an important role in the control system. The drag coefficient is affected by the shape and thickness of the valves [17].
The vibrating amplitude of a piezoelectric device produces an oscillating flow and alters the chamber volume by changing the curvature of the diaphragm. In Figure 3, when the actuator moves downward to decrease the chamber volume, the outflow will be in one direction with the inlet valve closed and the outlet valve open. When the actuator moves upward to increase the chamber volume, the inflow will be into the chamber with the inlet valve open and the outlet valve closed. The flow field may be disturbed if the valves are not harmonically oscillating with the PZT device. Improper valve functioning may cause the inlet valve to close and stop the working fluid from flowing into the chamber when the PZT device moves outward.

The definition of Reynolds number is

$$
\mathrm{Re}=\frac{\rho V D}{\mu},
$$

where $V=$ (mass flow rate) $/($ chamber cross-section area).

\section{Experiment Setup}

The fuel/ethanol injection system with a piezoelectric device is driven by an alternating sine-wave input. The input signal is controlled by a function generator. A sine-wave signal shown in Figure 4 is sent by the function generator to the piezoelectric device through the amplifier to amplify the signal. The flow rate data are recorded to analyze the fuel injection performance under a different input frequency and backpressure. The parameters of operating cases, as shown in Table 2, include dimensionless chamber depth and valve thickness. The operation alternative voltage of the piezoelectric device is chosen at $50 \mathrm{~V}$, and the vibrating frequency of the piezoelectric device is shifted from $1 \mathrm{~Hz}$ to $350 \mathrm{~Hz}$. The flow rate data are recorded to analyze the fuel injection performance under different frequencies. The flow chart of the experiment is shown in Figure 5.

\section{Results and Discussion}

4.1. Different Working Fluids. The measured flow rates of water and ethanol are shown in Figure 6. Obviously, the ethanol has a higher flow rate than water. In the case of $\mathrm{C}-1$, the maximum ethanol flow rate was $162 \mathrm{~mL} / \mathrm{min}$ at $f=60 \mathrm{~Hz}$, but the maximum water flow rate was only $87 \mathrm{~mL} / \mathrm{min}$ at $f=125 \mathrm{~Hz}$. In a similar trend, the maximum Reynolds number of ethanol is 569 at $f=60 \mathrm{~Hz}$, which is higher than the maximum Reynolds number of water at the same frequency, 459. This is because the ethanol has a smaller viscosity effect than water. The range of the Reynolds number in this study is 21 to 569 , and the flow can be regarded as the laminar flow. 


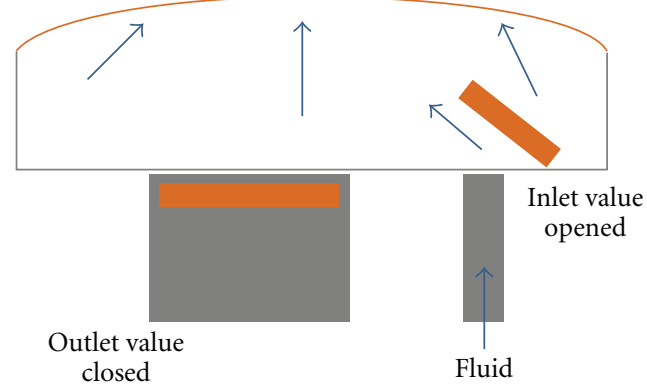

(a)

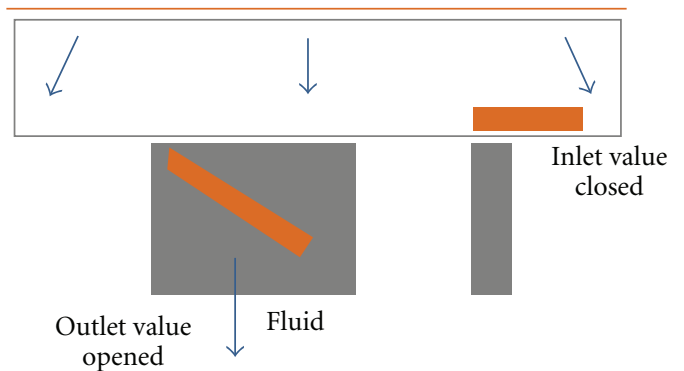

(b)

FIGURE 3: Actuating mechanisms in an ethanol injection system. (a) Sucked working fluid into the chamber. (b) Exhausted working fluid from the chamber.

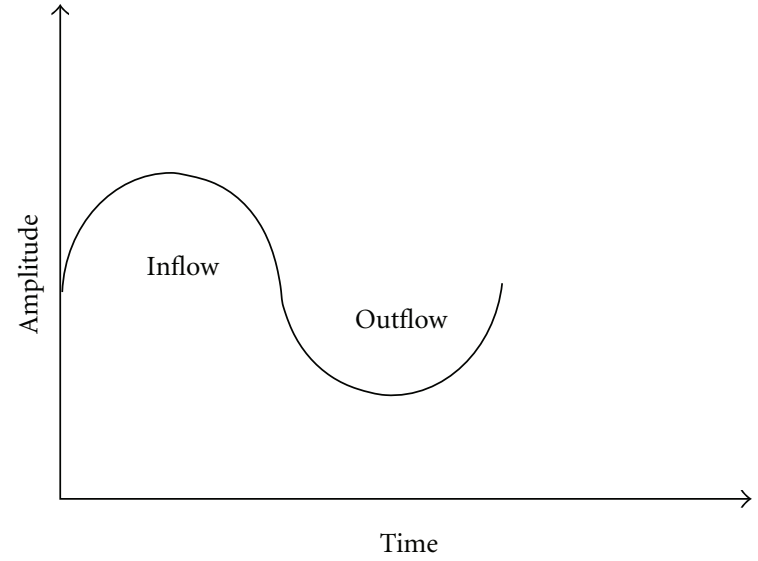

FIGURE 4: The sine function of periodical flow.

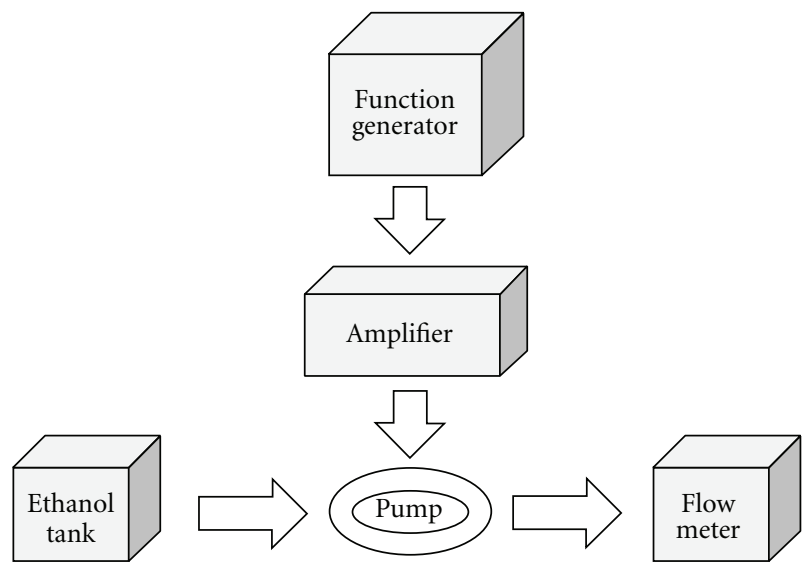

FIGURE 5: The flow chart of fuel injection system.

When the PZT vibrating frequency exceeded $100 \mathrm{~Hz}$, the limited ethanol flow rates were measured. However, the limited water flow rates were measured when the PZT vibrating frequency was over $300 \mathrm{~Hz}$. In Figure 7, the valve thickness has a significant effect on the flow rate. The major reason is that the valve thickness alters the vibration of the valve and causes a different flow rate. The results also show that the maximum ethanol flow rate $(170 \mathrm{~mL} / \mathrm{min})$ is found

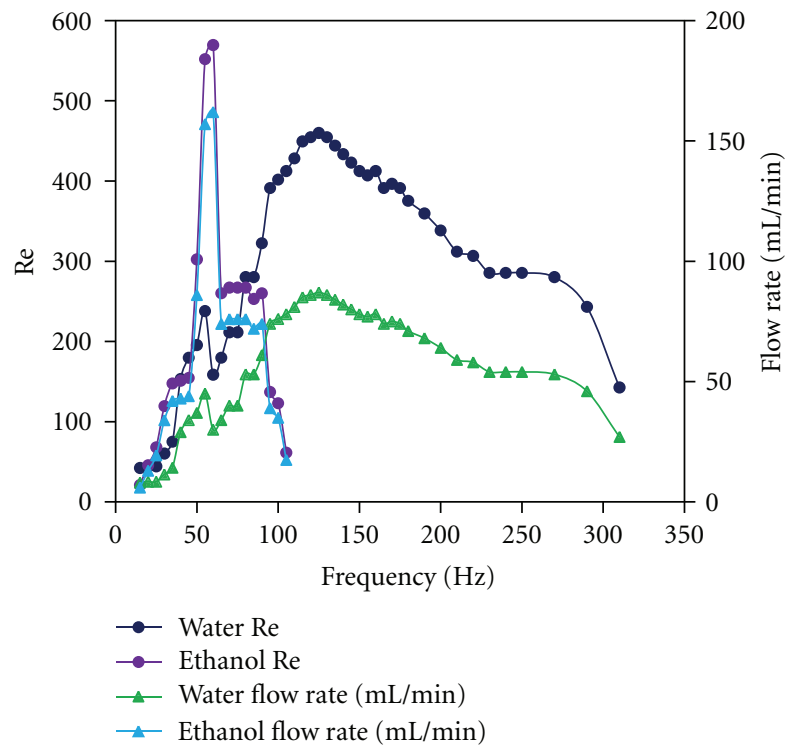

Figure 6: Measured flow rate under different frequency with different working fluids. (Case C-1).

in the thicker valve, $0.5 \mathrm{~mm}$. In addition, the flow rates of water crashed under $0.2 \mathrm{~mm}$ valve thickness around PZT = $75 \mathrm{~Hz}$.

4.2. Effect of Valve Thickness. In Figures 8 and 9, the maximum Reynolds number for water and ethanol are 697 and 597 , respectively. Ratio of $T / H$ is defined as a dimensionless parameter. Both of the maximum Reynolds numbers are found in large $T / H$ value $=0.25$. For low $T / H$ value $=0.10$, the Reynolds numbers are lowest at low PZT frequencies in both working fluids. Thus, the valve thickness is one of the important parameters in the fuel injection system.

4.3. Effect of Dimensionless Chamber Depth. Figures 10 and 11 indicate that the maximum Reynolds numbers of ethanol and water are found in smaller $H / D$ value $=0.043$, at the higher PZT frequencies. The maximum Reynolds numbers are 569 and 459 in ethanol and water, respectively. For higher $H / D$ values, 0.065 and 0.087 , both of the Reynolds numbers are significantly low at low PZT frequencies. Therefore, 


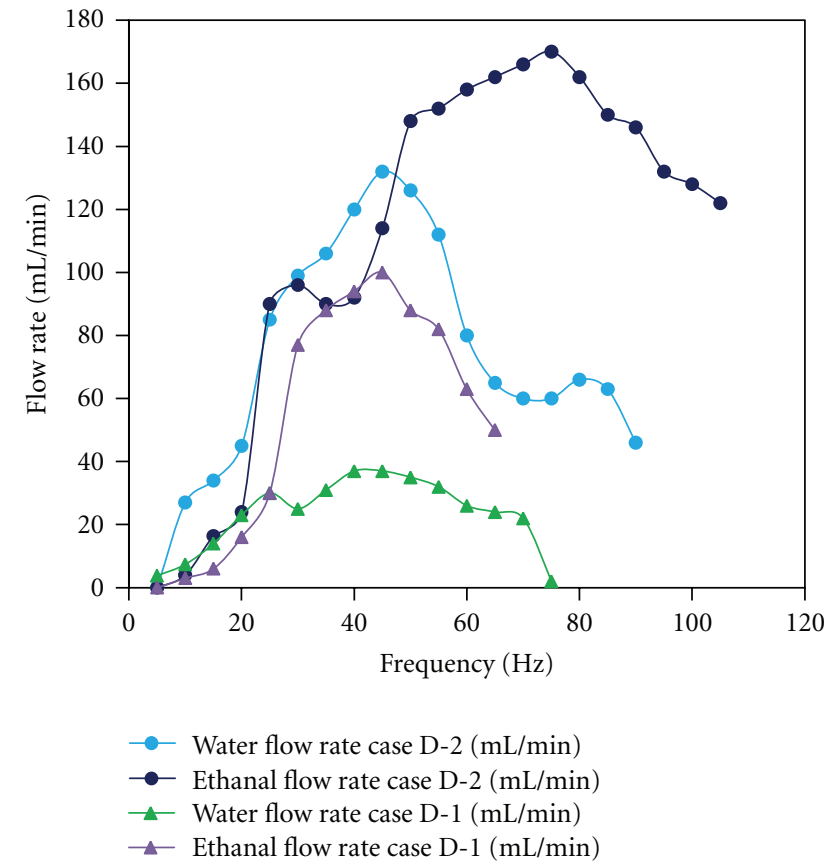

FIGURE 7: Measured flow rate under different frequency with different valve thickness. (Case D).

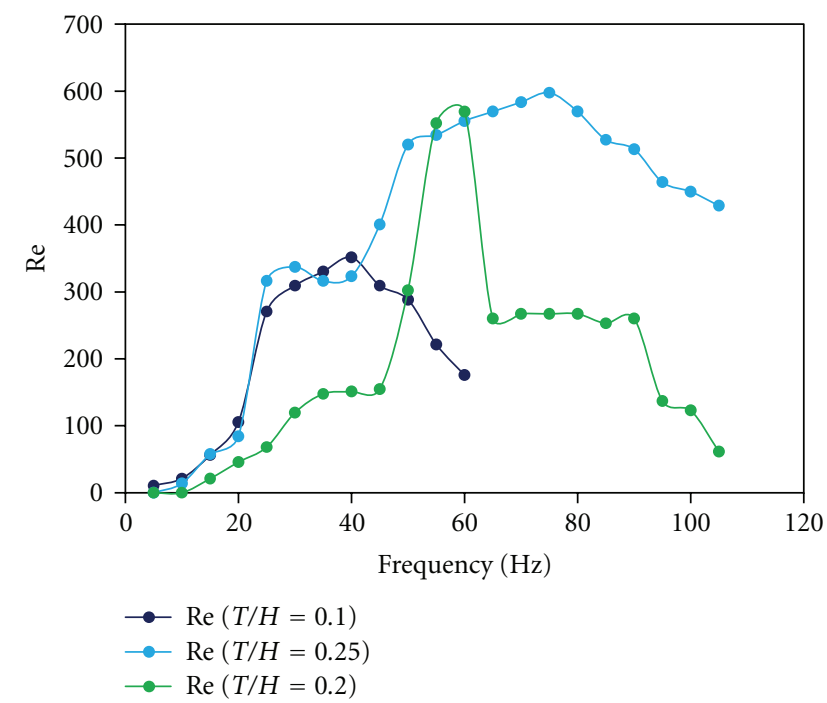

Figure 8: The Reynolds number of ethanol flow under different $T / H$ ratios.

the chamber depth is one of the most important parameters in the chamber design.

However, the maximum ethanol flow rate is larger than that of the water regardless of the chamber depth, as shown in Figure 12. Moreover, the maximum ethanol flow rate is $162 \mathrm{~mL} / \mathrm{min}$ at $f=60 \mathrm{~Hz}$ in the case C-1. Then, the ethanol flow rate has a sharp drop to $76 \mathrm{~mL} / \mathrm{min}$ when the PZT vibrating frequency reaches $65 \mathrm{~Hz}$. On the other hand, the maximum water flow rate is $87 \mathrm{~mL} / \mathrm{min}$ at $f=125 \mathrm{~Hz}$ in the case C-1. However, the water flow rate shows a slow drop to $27 \mathrm{~mL} / \mathrm{min}$ at the higher frequency of $310 \mathrm{~Hz}$.

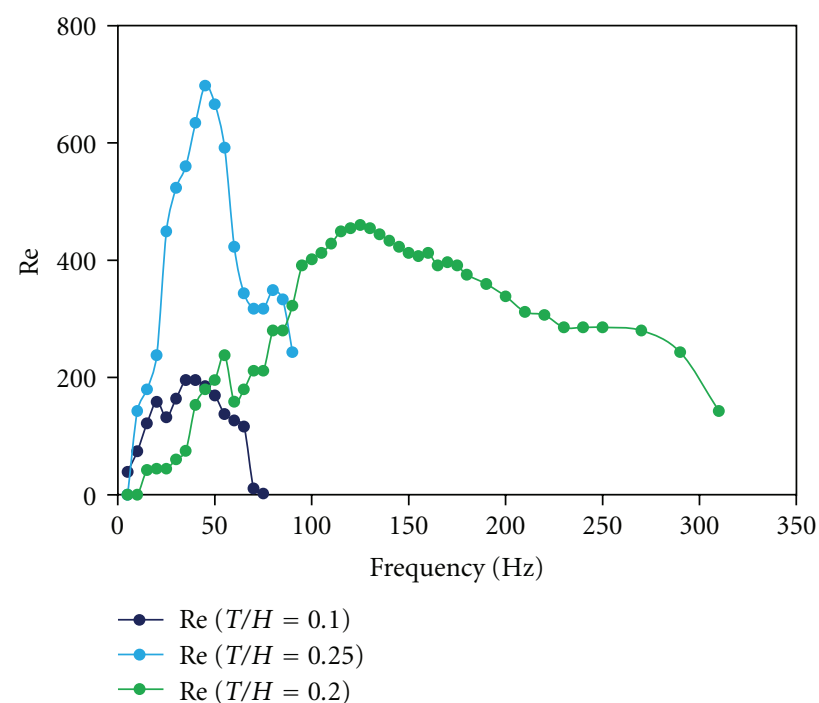

Figure 9: The Reynolds number of water flow under different $T / H$ ratios.

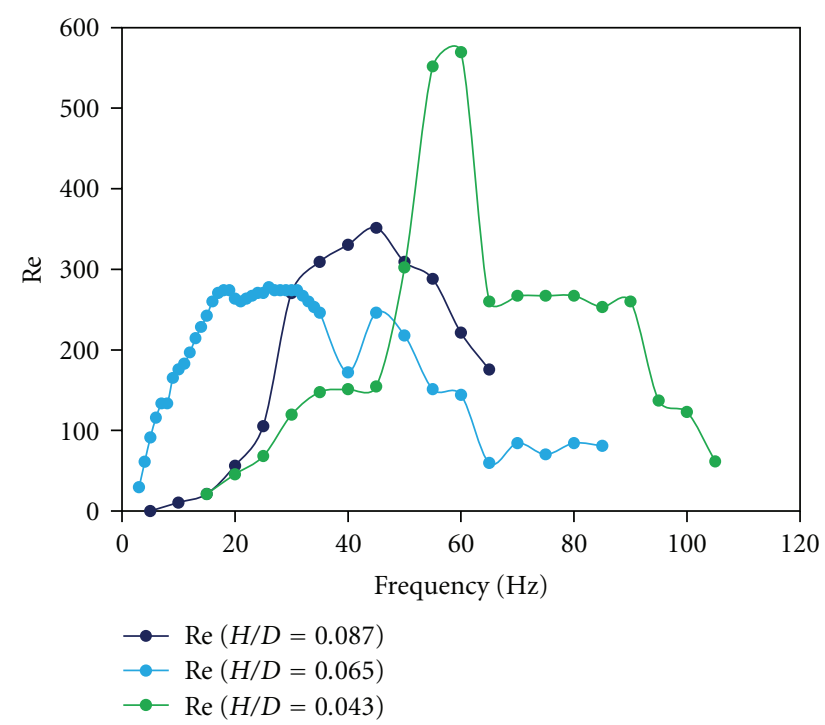

FIGURE 10: The Reynolds number of ethanol flow under different $H / D$ ratios.

4.4. Required Power of Ethanol Supply Piezoelectric (PZT) Pump. The flow rate is depended on the PZT vibration. Based on (1), the PZT vibration is assumed to be the sine function. When the maximum ethanol flow rate is $162 \mathrm{~mL} /$ min at $f=60 \mathrm{~Hz}$ and 50 volts, the power consumption is $0.675 \mathrm{~W}$. Thus, the microdirect alcohol fuel cells with power output larger than $0.675 \mathrm{~W}$ is suitable for the PZT device in this case.

\section{Conclusions}

The novel design of an ethanol injection system by using a microdiaphragm pump with a piezoelectric device has been 


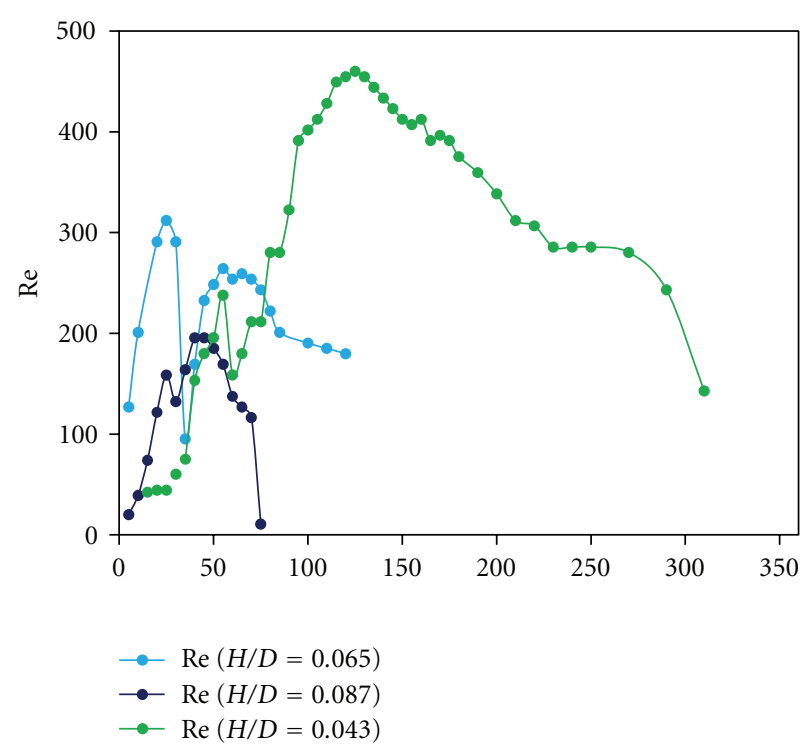

Figure 11: The Reynolds number of water under different $H / D$ ratios.

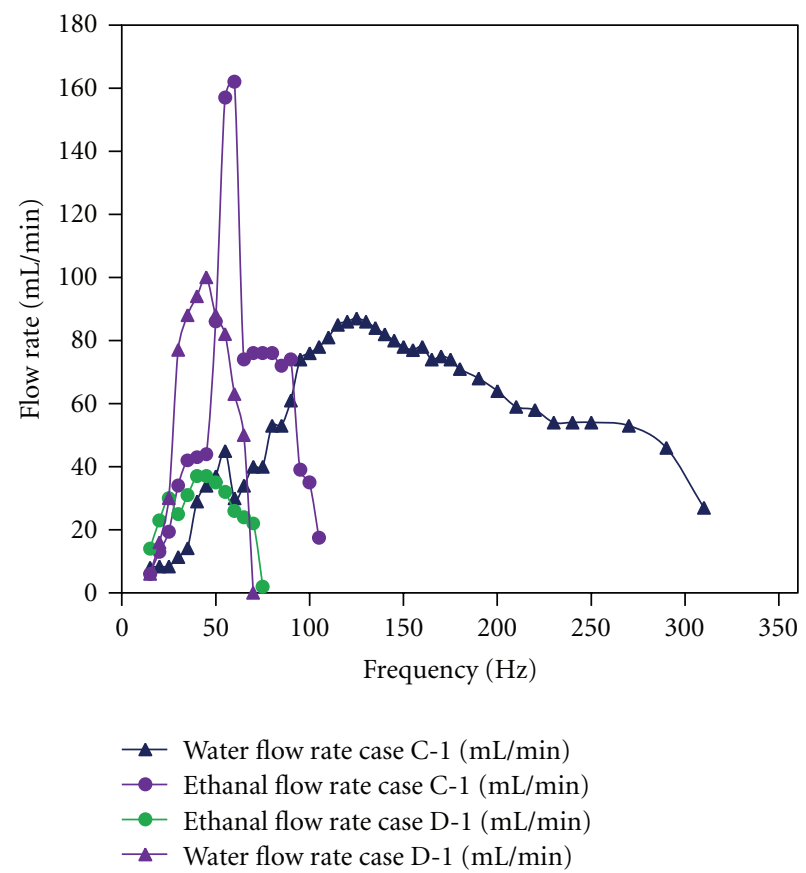

Figure 12: Measured flow rate under different frequency with different chamber depth.

successfully developed and tested. The major conclusions are summarized below.

(1) The ethanol has a higher flow rate than water. In the case $\mathrm{C}-1$, the maximum ethanol flow rate was $162 \mathrm{~mL} / \mathrm{min}$ at $f=60 \mathrm{~Hz}$, but the maximum water flow rate was only $87 \mathrm{~mL} / \mathrm{min}$ at $f=125 \mathrm{~Hz}$.

(2) The valve thickness has a significant effect on the flow rate. The maximum ethanol flow rate, $170 \mathrm{~mL} / \mathrm{min}$, was found in the thicker valve $(T / H=0.25)$ at $f=$ $75 \mathrm{~Hz}$.

(3) The chamber depth is one of the most important parameters in the chamber design. The maximum ethanol flow rate was $162 \mathrm{~mL} / \mathrm{min}$ in the shallow depth $(H / D=0.043)$ at $f=60 \mathrm{~Hz}$.

(4) The maximum water flow rate was $132 \mathrm{~mL} / \mathrm{min}$ in the Case D-2 chamber with the PZT vibrating frequency of $45 \mathrm{~Hz}$.

(5) When the maximum ethanol flow rate is $162 \mathrm{~mL} / \mathrm{min}$ at $f=60 \mathrm{~Hz}$ and 50 volts, the power consumption is $0.675 \mathrm{~W}$.

\section{Nomenclature}

$A_{\text {in }}: \quad$ Inlet area $\left(\mathrm{m}^{2}\right)$

$A_{\text {PZT }}$ : Piezoelectric area $\left(\mathrm{m}^{2}\right)$

amp.: Amplitude of PZT (m)

$D: \quad$ Chamber diameter $(\mathrm{m})$

$f: \quad$ Frequency of PZT $(\mathrm{Hz})$

$H: \quad$ Chamber depth (m)

$P: \quad$ Pressure $\left(\mathrm{N} / \mathrm{m}^{2}\right)$

Re: Reynolds number

$t: \quad$ Time (s)

$T: \quad$ Valve thickness (m)

$V_{\text {PZT }}$ : Motion equation of the piezoelectric device $(\mathrm{m} / \mathrm{s})$

$\forall: \quad$ Volume $\left(\mathrm{m}^{3}\right)$

M: $\quad$ Mass $(\mathrm{Kg})$

Mw: Molecular weight $(\mathrm{g} / \mathrm{mol})$

$n$ : Normal direction

n: Transport electricity's number

$\rho: \quad$ Density $\left(\mathrm{Kg} / \mathrm{m}^{3}\right)$.

\section{Subscript}

CS: Control surface

$\mathrm{CV}$ : Control volume

In: Inlet

PZT: Piezoelectric device

$\mu$ : Viscosity.

\section{Acknowledgment}

This research was funded by the National Science Council of the R.O.C. (NSC 99-2221-E-002-126-MY2).

\section{References}

[1] U. B. Demirci, "Direct liquid-feed fuel cells: thermodynamic and environmental concerns," Journal of Power Sources, vol. 169, no. 2, pp. 239-246, 2007.

[2] S. Böhm, W. Olthuis, and P. Bergveld, "Plastic micropump constructed with conventional techniques and materials," Sensors and Actuators A, vol. 77, no. 3, pp. 223-228, 1999.

[3] M. Koch, N. Harris, A. G. R. Evans, N. M. White, and A. Brunnschweiler, "Novel micromachined pump based on thick-film piezoelectric actuation," in Proceedings of 
the International Conference on Solid-State Sensors and Actuators, pp. 353-356, June 1997.

[4] BO. Li, Q. Chen, D. G. Lee, J. Woolman, and G. P. Carman, "Development of large flow rate, robust, passive micro check valves for compact piezoelectrically actuated pumps," Sensors and Actuators A, vol. 117, no. 2, pp. 325-330, 2004.

[5] L. Saggere, N. W. Hagood, D. C. Roberts et al., "Design, fabrication, and testing of a piezoelectrically driven high flow rate micro-pump," in Proceedings of the 12th IEEE International Symposium on Applications of Ferroelectrics, vol. 1, pp. 297300, August 2000.

[6] H. Suzuki and R. Yoneyama, "Integrated microfluidic system with electrochemically actuated on-chip pumps and valves," Sensors and Actuators B, vol. 96, no. 1-2, pp. 38-45, 2003.

[7] E. Stemme and G. Stemme, "A valveless diffuser/nozzle-based fluid pump," Sensors and Actuators A, vol. 39, no. 2, pp. 159167, 1993.

[8] A. Olsson, G. Stemme, and E. Stemme, "Diffuser-element design investigation for valve-less pumps," Sensors and Actuators A, vol. 57, no. 2, pp. 137-143, 1996.

[9] A. Olsson, G. Stemme, and E. Stemme, "Numerical and experimental studies of flat-walled diffuser elements for valve-less micropumps," Sensors and Actuators A, vol. 84, no. 1, pp. 165$175,2000$.

[10] A. Olsson, P. Enoksson, G. Stemme, and E. Stemme, "Valveless planar pump in silicon," in Proceedings of the 8th International Conference on Solid-State Sensors and Actuators and Eurosensors, pp. 291-294, June 1995.

[11] W. L. Benard, H. Kahn, A. H. Heuer, and M. A. Huff, "Thinfilm shape-memory alloy actuated micropumps," Journal of Microelectromechanical Systems, vol. 7, no. 2, pp. 245-251, 1998.

[12] O. Francais, I. Dufour, and E. Sarraute, "Analytical static modelling and optimization of electrostatic micropumps," Journal of Micromechanics and Microengineering, vol. 7, no. 3, pp. 183$185,1997$.

[13] A. Olsson, G. Stemme, and E. Stemme, "An improved valveless pump fabricated using deep reactive ion etching," in Proceedings of the IEEE 9th International Workshop on Micro Electro Mechanical Systems (MEMS '96), San Diego, Calif, USA, 1996.

[14] A. Olsson, G. Stemme, and E. Stemme, "Simulation studies of diffuser and nozzle elements for valve-less micropumps," in Proceedings of the International Solid State Sensors and Actuators Conference (Transducers '97), Chicago, Ill, USA, 1997.

[15] A. Olsson, O. Larsson, J. Holm, L. Lundbladh, O. Öhman, and G. Stemme, "Valve-less diffuser micropumps fabricated using thermoplastic replication," in Proceedings of the IEEE 10th International Workshop on Micro Electro Mechanical Systems (MEMS '97), Nagoya, Japan, 1997.

[16] X. Yang, Z. Zhou, H. Cho, and X. Luo, "Study on a PZTactuated diaphragm pump for air supply for micro fuel cells," Sensors and Actuators A, vol. 130-131, pp. 531-536, 2006.

[17] H. K. Ma, B. R. Hou, H. Y. Wu, C. Y. Lin, J. J. Gao, and M. C. Kou, "Development and application of a diaphragm micropump with piezoelectric device," Microsystem Technologies, vol. 14, no. 7, pp. 1001-1007, 2008.

[18] H. K. Ma, B. R. Hou, C. Y. Lin, and J. J. Gao, "The improved performance of one-side actuating diaphragm micropump for a liquid cooling system," International Communications in Heat and Mass Transfer, vol. 35, no. 8, pp. 957-966, 2008.

[19] T. Zhang and Q. M. Wang, "Valveless piezoelectric micropump for fuel delivery in direct methanol fuel cell (DMFC) devices," Journal of Power Sources, vol. 140, no. 1, pp. 72-80, 2005.
[20] H. K. Ma, S. H. Huang, B. R. Chen, and L. W. Cheng, "Numerical study of a novel micro-diaphragm flow channel with piezoelectric device for proton exchange membrane fuel cells," Journal of Power Sources, vol. 180, no. 1, pp. 402-409, 2008.

[21] H. K. Ma and S. H. Huang, "Development of microdiaphragm flow channel with piezoelectric effect in polymer electrolyte fuel cells," Journal of Fuel Cell Science and Technology, vol. 6, Article ID 034501, 2009.

[22] H. K. Ma, S. H. Huang, and Y. Z. Kuo, "A novel ribbed cathode polar plate design in piezoelectric proton exchange membrane fuel cells," Journal of Power Sources, vol. 185, no. 2, pp. 11541161, 2008.

[23] H. K. Ma, S. H. Huang, J. S. Wang, C. G. Hou, C. C. Yu, and BO. R. Chen, "Experimental study of a novel piezoelectric proton exchange membrane fuel cell with nozzle and diffuser," Journal of Power Sources, vol. 195, no. 5, pp. 1393-1400, 2010.

[24] H.-K. Ma, J.-S. Wang, and Y.-T. Chang, "Development of a novel pseudo bipolar piezoelectric proton exchange membrane fuel cell with nozzle and diffuser," Journal of Power Sources, vol. 196, no. 8, pp. 3766-3772, 2011. 


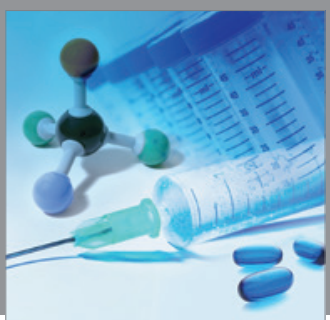

International Journal of

Medicinal Chemistry

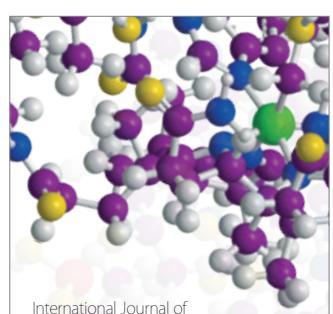

Carbohydrate Chemistry

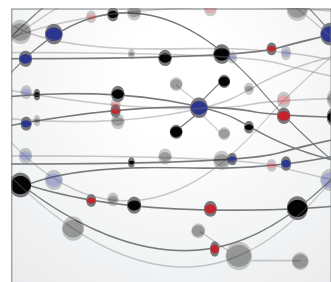

The Scientific World Journal
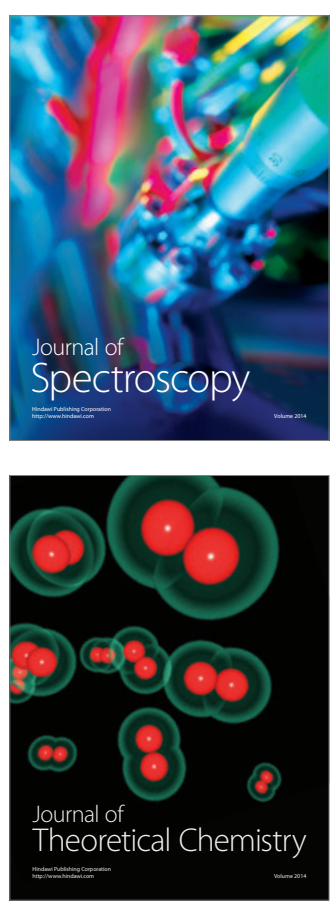
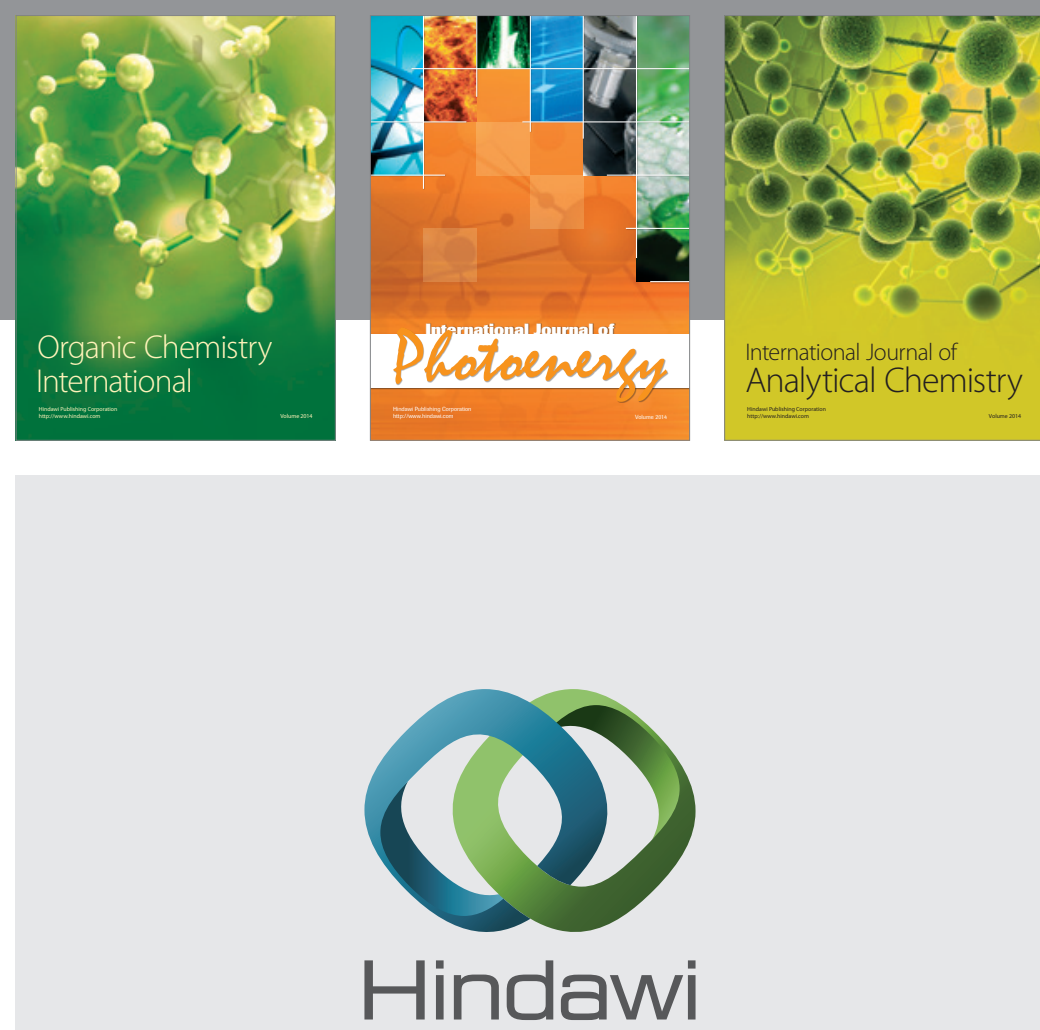

Submit your manuscripts at

http://www.hindawi.com
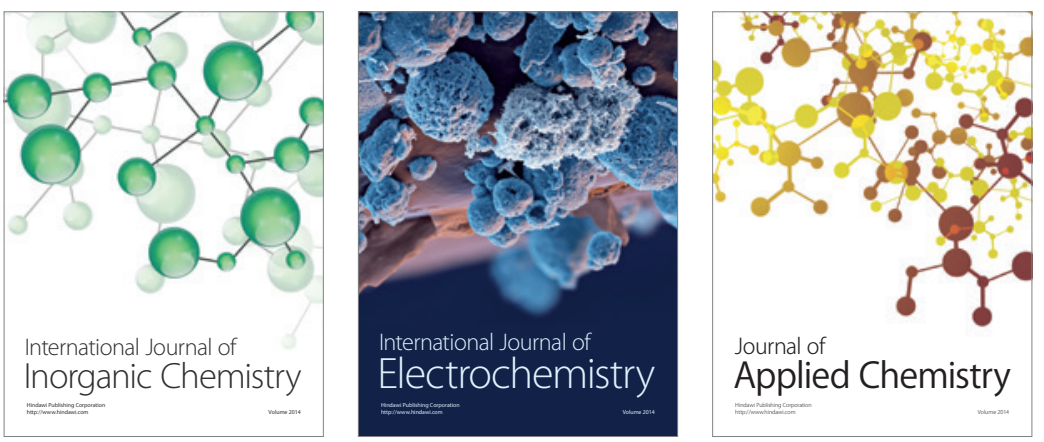

Journal of

Applied Chemistry
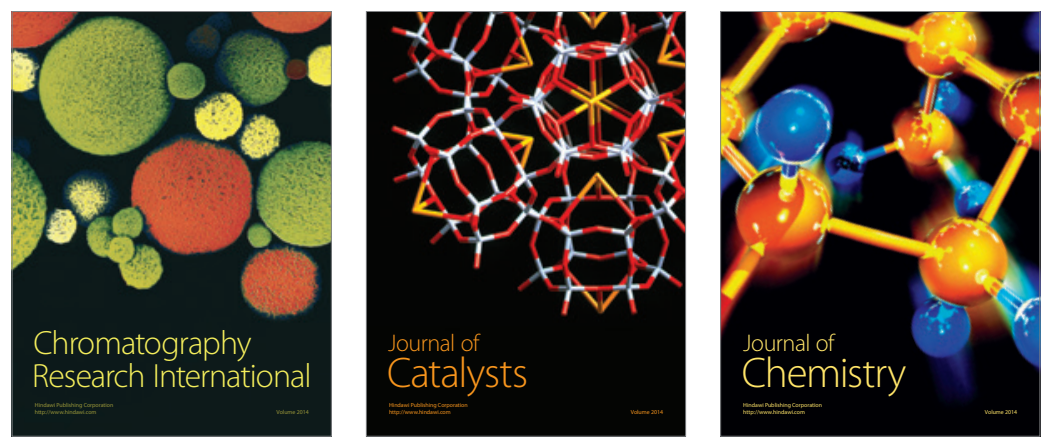
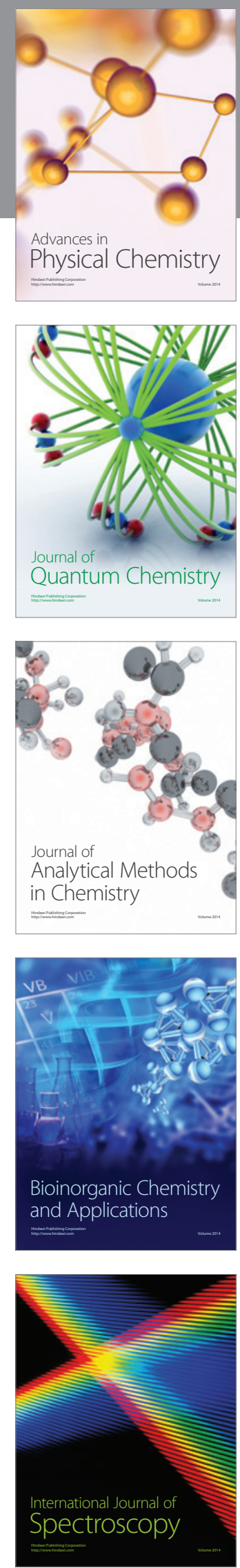